\title{
THE LATE-SURVIVING SNOW-BED ON CARNEDD LLEWELYN
}

\author{
By S. E. ASHMORE
}

IN mountainous regions of the British Isles certain gullies are to be found containing snow-beds which habitually persist well into the summer and, indeed, have on occasion given rise to the belief that they might provide small permanent glaciers. Y Ffos Ddyfn, a gully of this kind, exists near the summit of Carnedd Llewelyn and has acquired the reputation of being the place where snow lies latest in England and Wales. This is remarkable in view of its geographical position and the fact that it faces almost due south. The gully was studied by the late J. R. Gethin Jones,* but subsequently its position could not be ascertained. Since his death in 1920 a number of attempts have been made to identify it, and on 26 May 1947 I was able to rediscover it. The bottom, described in 1910 as covered with earth and stones, had become very rugged and rocky. Torrents of water evidently rush down at times, although there is no permanent stream.

After the exceptional snows of the winter of 1947 , I felt confident of finding enough snow in it to survive until the next winter. I was therefore surprised to find only one small irregular patch, about $4 \mathrm{ft}$. $(1 \cdot 2 \mathrm{~m}$.) by $\mathrm{I} \mathrm{ft}$. $(0.3 \mathrm{~m}$.) and 2 in. $(5 \cdot 1 \mathrm{~cm}$.) deep. Gethin Jones recorded having found the snow somewhat dirty, and assumed that industrial smoke was the cause, but he was unable to explain the patchiness of the deposits. The snow I found in May 1947 looked as though it had received a liberal coating of bitumen. Around the edges of the melting snow there was black froth and the rocks appeared as if bespattered with tar. A quantity of this dry deposit was collected and later analysed through the kindness of Professor J. McLean Thompson of Liverpool University. He found that it was devoid of organic content and consisted of extremely finely disintegrated mica-schist, rich in micro-crystals of quartz, felspar and biotite. It appears that the long continuance of the snow-bed and the fluctuating movements of the snow had led to extensive erosion and that the products of erosion had gradually worked to the top. These processes would operate on a large scale in a year such as 1947 owing to the rapidly recurrent heavy additions of snow, accompanied by much movement of the lowest layer. The snow I found was very hard, like firn-ice, and flow on a small scale might actually have occurred. Snow without discoloration is likely to be found when a bed has been formed recently before much movement has taken place or when it has been caused by one large snowfall.

According to Gethin Jones, y Ffos Ddyfn was full of snow on I6 May 1910, after a winter far from severe. One naturally seeks an explanation of the early disappearance of snow in 1947 after a winter of historic severity. Various data have been computed for each year for which the approximate date of the disappearance of the winter snow in y Ffos Ddyfn is known. Fig. I (p. 206) presents the information graphically: for each year, during the period in which snow lay, the monthly rainfall is shown by a block, the actual mean temperature by a full line and the average mean temperature by a broken line. A wind rose is given for each month. Since no observations have been made in the gully itself, the data are approximations. There was, each winter, a period during which snow lay continuously, and the date of its disappearance is entered on the diagram. Sometimes, however, the snow-bed disappeared early in the year and late spring snows, usually wet and with little drifting, lay in the gully for a further period. For 1947 and 1948 the dates of disappearance of this late spring snow are also known and are entered below the dates of disappearance of the winter snow-bed.

* Jones, J. R. Gethin. The spot in England and Wales where snow lies latest. British Rainfall, 49th Annual Volume,
1909, p. 46-53. 

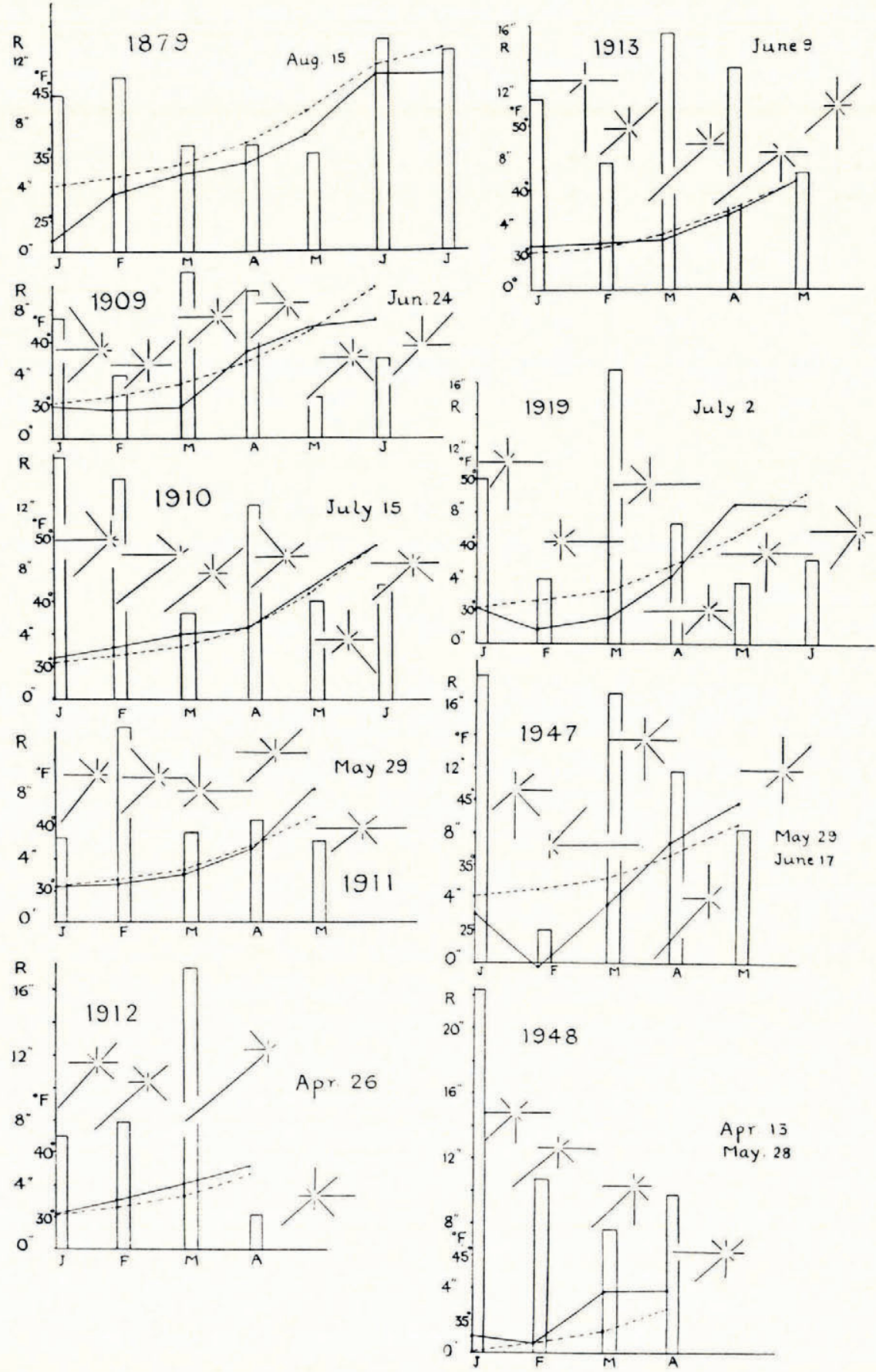

Fig. I. Chart of meteorological conditions in y Ffos Ddyfn Area (see text p. 205) 
Gethin Jones refers to a year, which I think must have been 1879 , when snow lay in y Ffos Ddyfn until the middle of August.

In 1909 a very cold March with heavy snows was chiefly responsible for the snow-bed; a further considerable addition was made late in April. But, as seen from the wind rose, there were few winds from the north, which is the direction of longest drift lines.

1910 is the year lealt with in detail by Gethin Jones. The gully was full to overflowing, remaining so up to mid-May. The south-west drift lines are long ones, and it is easy to see how the gully came to be filled so readily. The northerly winds, although less frequent, helped the drifting.

In I9 I most of the snow fell in February, and drifting, accompanying the prevalent southwest winds, would fill the gully from the side, causing large drifts there, but preventing the rest of the gully from being filled. As temperatures were mainly below normal during the spring and southerly winds infrequent, the drifts were able to survive until the heat at the end of May.

The winter of I9I I-12 was unusually mild and the snow-bed vanished before the end of April.

In 1913 the chief feature of the snowfall was the heavy March deposit, with much drifting from the south-west. Apart from earlier falls, io ft. $(3 \mathrm{~m}$.) of snow must have fallen in March alone; but as it drifted in from one side, only about half the gully was filled. This accumulation enabled the snow-bed to last into June.

The winter of 1918-19 was very snowy and cold. After the severe storm at the end of April, which was the last snowfall of the season, the gully was over-full and kept its snow through the blazing sunshine of May. On 3 June the bed was $45 \mathrm{yd}$. (4I m.) long, the greatest width being ro yd. ( $9 \mathrm{~m}$.), and it probably did not disappear until the warm rain of 2 July.

The extremely severe conditions in 1947 are still fresh in the memory. Some of the snow from the early January blizzards was melted by several inches of warm rain in mid-month. Although the Carnedd range escaped much of the snow which fell further east in Wales, the snow which had already accumulated was enormously augmented in March and up to 8 April. The gully not only became full but probably had large drifts above the general level. The deposit became very hard, like ice. It is difficult to explain the rapid disappearance of such large quantities of hard snow, but the critical factor was probably the prevalence of warm rains during the spring, which are the most effective agency for snow removal.

In 1948 , which provided a complete meteorological contrast to the previous year, the whole accumulation had disappeared by 10 April. During this season observations made by $\mathrm{Mr}$. W. $\mathrm{H}$. Ward bear out my belief that in mild winters snow patches persist in other localities as long as in y Ffos Ddyfn. Mr. Ward also called attention to an abnormal amount of scree movement, due to rapid melting of snow in the winter.

In conclusion, after studying the behaviour of this snow-bed over several seasons, one is led to believe that the retention of snow is not so remarkable as one would gather after reading Gethin Jones' report on the year I9Io. Even with the gully full, disappearance of snow can be rapid given favourable conditions. Nevertheless it is thought that if a season a trifle colder than 1879 were to follow a severe winter, we should have a snow-bed able to survive the summer.

I wish to express gratitude to Mr. E. L. Hawke and to others who have assisted me in different ways in making this report. 